OPEN ACCESS

Edited by:

Pierlorenzo Pallante, Italian National Research Council

(CNR), Italy

Reviewed by:

Carlos Teixeira Brandt,

Federal University of

Pernambuco, Brazil

Mariangela Russo,

University of Turin, Italy

${ }^{*}$ Correspondence:

Ke Wang

keewang@hotmail.com

Jinliang Kong

kjl071@163.com

Specialty section:

This article was submitted to Gastrointestinal Cancers,

a section of the journal

Frontiers in Oncology

Received: 17 September 2018 Accepted: 08 November 2019 Published: 27 November 2019

Citation:

Bao C, Wang K, Ding Y and Kong J (2019) Association Between Anti-bacterial Drug Use and Digestive

System Neoplasms: A Systematic Review and Meta-analysis. Front. Oncol. 9:1298 doi: 10.3389/fonc.2019.01298

\section{Association Between Anti-bacterial Drug Use and Digestive System Neoplasms: A Systematic Review and Meta-analysis}

\author{
Chongxi Bao, Ke Wang*, Yudi Ding and Jinliang Kong* \\ Department of Respiratory Disease, First Affiliated Hospital of Guangxi Medical University, Nanning, China
}

Background: Anti-bacterial drugs are thought to be associated with several malignancies.

Objective: We conducted a systematic review and meta-analysis to assess the association between antibacterial drug exposure and the risk of digestive system neoplasms.

Methods: Relevant publications reporting a relationship between antibiotic use and the risk of cancer were identified in PubMed, EMBASE, and Cochrane Central Register through June 2018. The random-effects model was selected to pool the risk ratios (RRs) and determine $95 \%$ confidence intervals (95\% Cls). We performed subgroup analyses by tumor organ site, individual antibacterial drug class, and drug dose accumulation.

Results: A total of 17 eligible studies (four randomized trials and 13 observational studies) involving 77,284 cancer patients were included in our analyses. Anti-bacterial drug exposure slightly increased the risk of overall digestive system cancer (RR, 1.12; 95\% Cl, 1.10-1.14), stomach and small intestine (RR, 1.12; 95\% Cl, 1.07-1.17), anorectocolonic (RR, 1.08; 95\% Cl, 1.05-1.12), and hepatobiliary and pancreatic cancers (RR, 1.18; 95\% Cl, 1.14-1.22). For different anti-bacterial drugs classes, nitroimidazoles $(R R, 1.17 ; 95 \% \mathrm{Cl}, 1.09-1.26)$ and quinolones $(R R, 1.18 ; 95 \% \mathrm{Cl}$, 1.11-1.26) showed a modest association with the risk of cancers incidence. The risks of digestive system cancers increased with the rise of drug dose accumulation: low (RR, $1.08 ; 95 \% \mathrm{Cl}, 1.05-1.11)$, intermediate (RR, 1.15; $95 \% \mathrm{Cl}, 1.12-1.18)$, and high (RR, $1.22 ; 95 \% \mathrm{Cl}, 1.18-1.26)$.

Conclusions: Anti-bacterial drug exposure was associated with the risks of digestive system cancer occurrence in our analysis.

Keywords: anti-bacterial drugs, cancers, risk, systematic review, meta-analysis

\section{INTRODUCTION}

Digestive system cancers, such as esophageal, stomach and small intestine, anorectocolonic, hepatobiliary, and pancreatic cancers, are a global threat to human health and a leading cause of cancer death (1-3). The identification of etiological factors is important to preventing the occurrence of these cancers and decreasing death rates. Relevant publications have suggested the 
hypothesis that the use of certain drugs is associated with cancer development $(4,5)$, and that the regular use of antibacterial drugs is involved (6). The risk of several malignancies, such as lung (7), hematologic (8), and breast cancer (9), are reportedly associated with anti-bacterial drug exposure. The risk of colorectal and several other digestive cancers have also been evaluated in previous studies $(10,11)$. To our knowledge, there have not been any systematic reviews or meta-analyses examining the association between digestive system cancers and antibacterial drugs.

With the concern of the global, widespread use of antibacterial agents, the effects on drug-induced cancer create uncertainty. We conducted a systematic review and metaanalysis to assess the association between the risk of digestive neoplasms and anti-bacterial drug exposure.

\section{METHODS}

We performed the systematic review based on the Preferred Reporting Items for Systematic Reviews and Meta-analyses guidelines (12). The protocol for our meta-analysis was documented online (PROSPERO registry- CRD42018098646).

\section{Data Sources and Search}

A search of the relevant publications (in English) up to June 2018 was conducted in PubMed, EMBASE, and the Cochrane central register. Case-control, cohort studies, and randomized control trials (RCT) were identified by searching with the following Medical Subject Heading (Mesh) terms and text words: "neoplasms," "tumors," "tumor," "cancer," “cancers," "malignant neoplasms," "neoplasm," and "anti-bacterial agents," "anti-bacterial compounds," "anti-infective agents," "antimycobacterial agents," and "risk." Additional literature was searched by scanning the reference lists of included studies. Abstracts and titles were reviewed in the primary search independently by both investigators (Bao Chongxi, Ding Yudi). Potentially relevant articles were evaluated in detail, and disagreements between investigators were resolved by consensus. Studies were included if they met the following criteria: (1) Study reported the association between antibiotic exposure and the digestive system cancer risk; (2) Study provided four-fold table data or effect sizes, such as risk ratio (RR), relative risk (RR), and odds ratio (OR); (3) Study used prospective or retrospective, cohort or (nested) case-control designs. When multiple articles originated from the same population, we would combine these articles into one study, and used the most applicable data, or data with the longest follow-up duration.

\section{Data Abstraction}

Two investigators extracted all data independently (Chongxi Bao, Yudi Ding). Data was double checked for accuracy after finishing the individual work, and arguments were resolved by discussion. Information needed for the meta-analysis that was absent from any of the selected studies was obtained by contacting the authors via email. The following data were extracted from each included study: journal name, first author name, publication year, country or region, study type (case-control studies/cohort studies/nested case-control studies/RCTs), follow-up period, total patients, number of anti-bacterial drugs exposed to (which could include 0 ), detailed prescription of anti-bacterial drug use, RRs, ORs, or SIRs, and the corresponding 95\% confidence intervals (CIs).

\section{Quality Assessment}

The two investigators (Ke Wang, Jinliang Kong) used the Newcastle-Ottawa Scale (NOS) to assess the quality of cohort or nested case-control studies independently (13), and a study of high quality was defined as one with seven or more stars $(13,14)$. The quality of the included RCTs was evaluated using the Cochrane risk of bias tool (15).

\section{Statistical Analysis}

All data analyses were performed using the COMPREHENSIVE META-ANALYSIS software version 3.0 (Biostat, Englewood, NJ). A significant degree of heterogeneity between studies was defined using the $I^{2}$ statistic value $(16,17)$, and the random effects model was selected according to heterogeneity $\left(p<0.1, I^{2}>50 \%\right)(17)$. Publication bias was examined by Egger's regression asymmetry test and funnel plot $(18,19)$. Given that digestive cancers occur rarely in the general population, the distortions of various effect sizes (RR, OR, SIR) were ignored, and we used RR as the general effect size $(20,21)$.

We performed subgroup analyses according to different digestive system organ sites involving the esophagus, stomach and small intestine, anorectocolonic, hepatobiliary system, and pancreas $(9,10)$. Risks of digestive system cancers associated with individual anti-bacterial drug exposure were also assessed. The potential effect of drug dose accumulation on tumor development was evaluated by the subgroups: low, intermediate, and high cumulative prescription doses (22). Drug dose cumulative grade was based on the percentile of prescriptions or treatment courses within users: low (prescriptions/courses $<2$ ), intermediate (prescriptions/courses 2-5), and high (prescriptions/courses $>5)(10,23)$. Considering that cancer development is a step-wise process occurring over a period of several years, we conducted subgroup analyses by follow-up period before cancer diagnosis based on 25 and $50 \%$ of the duration (years). RR (95\% CIs) for subgroups of tumor sites, categorical anti-bacterial drugs, and drug dose cumulative grades were calculated.

\section{RESULTS}

\section{Included Studies and Study Characteristics}

A total of 4,392 articles were initially identified from the search in the selected databases and 78 articles were retrieved and further reviewed after the screening of titles and abstracts. We ultimately identified 17 eligible studies including 13 observational studies $(6,9-11,23-31)$ (cohort and nested case-control) and four RCTs (32-35) (Figure 1). The characteristics of the included studies are summarized in Table 1. These studies included 77,284 cancer patients from 18,205,771 individuals. Anti-bacterial drugs were used to eradicate helicobacter pylori ( $\mathrm{Hp})$ in seven studies (29-35), and two study cohorts consisted of patients with peptic ulcer disease. Detailed anti-bacterial agent classifications 


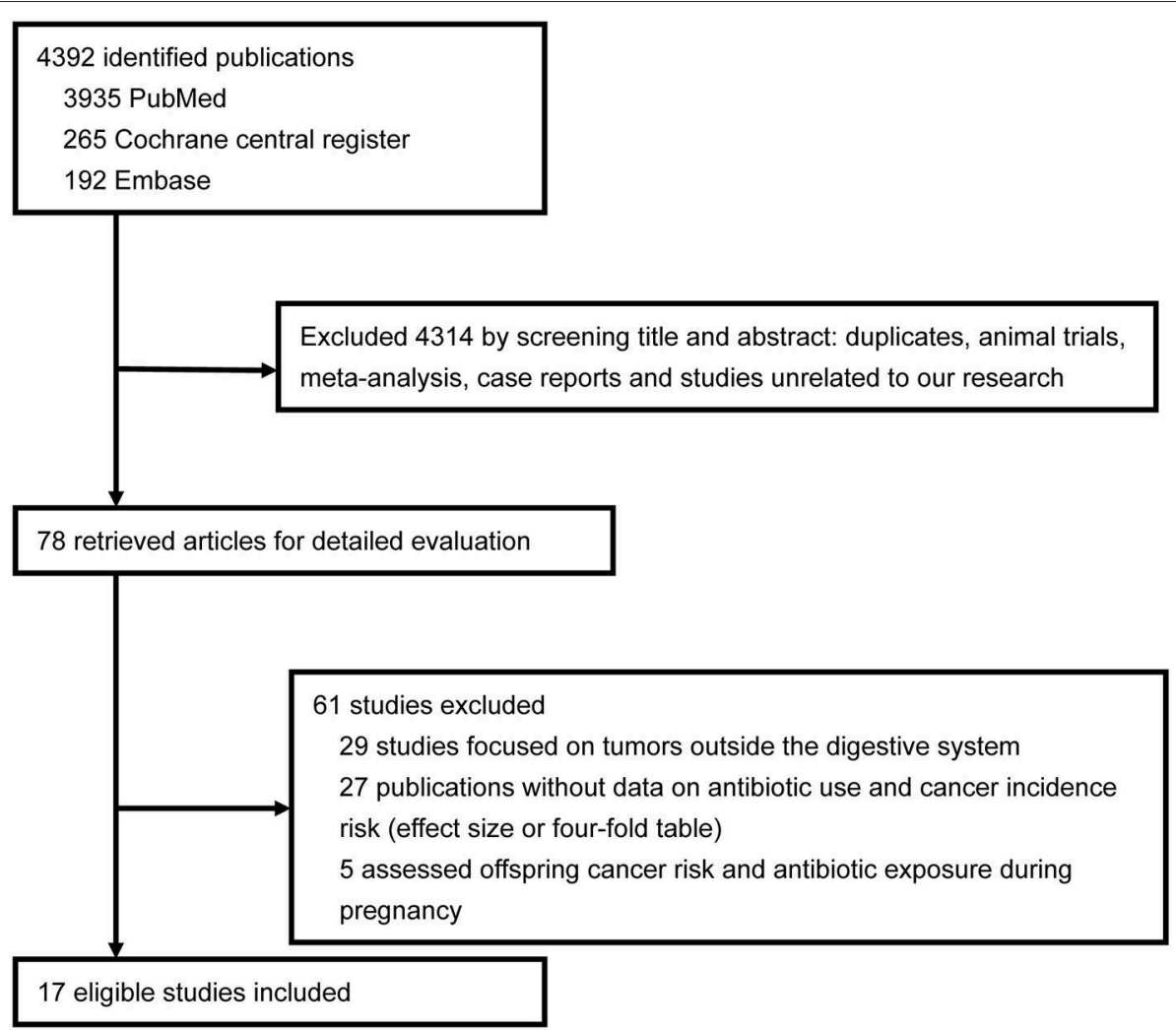

FIGURE 1 | Flowsheet of literature search and study selection.

were not provided in seven of the above studies, and we classified another four studies $(9,24,25,28)$ as unknown with regard to anti-bacterial drug class subgroup. For the risk evaluation outcome data, the number of cancer patients with anti-bacterial drug exposure (or not) was shown in 11 studies (Supplementary Table 1), RR (95\% CIs) was shown in three studies, SIR (95\% CIs) was shown in two studies, and OR (95\% CIs) was shown in one study. Drug dose accumulation data (prescriptions or treatment courses) was obtained from six studies $(10,11,23,25,27,28)$. All of the included studies excluded patients with only a 1-2 years interval before cancer diagnosis because the cancers were unlikely to develop in such a short time.

\section{Study Quality, Publication Bias, and Heterogeneity}

Thirteen observational studies were of significant high quality (scores ranged from 7 to 9) and four RCTs were assessed as moderate or high quality (Supplementary Tables 2, 3). Egger's test $(p=0.68)$ and funnel plot (Supplementary Figure 1) did not indicate obvious publication bias. We conducted sensitivity analyses after excluding individual studies, and no excessive differences in summary outcomes were observed. The random effects model was selected to pool the RR (95\% CIs) for statistically significant heterogeneity $\left(p<0.01, I^{2}=77 \%\right)$.

\section{Overall Anti-bacterial Drug Exposure and Digestive System Cancer Risk}

An increased risk of total digestive system cancers was associated with whole anti-bacterial drug exposure (RR, 1.12; 95\% CI, 1.10-1.14). Slightly elevated cancer risks related to anti-bacterial drugs were also demonstrated in subgroups of stomach and small intestinal (RR, 1.12; 95\% CI, 1.07-1.17), anorectocolonic (RR, 1.08; 95\% CI, 1.05-1.12), hepatobiliary, and pancreatic cancers (RR, 1.18; 95\% CI, 1.14-1.22). However, esophageal cancer (RR, 1.05; 95\% CI, 0.99-1.10) showed no relationship to anti-bacterial drug use (Figure 2, Table 2). For the nine individual antibacterial drug groups, cephalosporins (RR, 1.12; 95\% CI, 1.051.18), macrolides (RR, 1.09; 95\% CI, 1.04-1.15), nitroimidazoles (RR, 1.17; 95\% CI, 1.09-1.26), penicillins (RR, 1.08; 95\% CI, 1.041.14), sulphonamides (RR, 1.09; 95\% CI, 1.03-1.14), quinolones (RR, 1.18; 95\% CI, 1.11-1.26), and the group of unknown anti-bacterial drugs (RR, 1.20; 95\% CI, 1.16-1.25) statistically increased the risk of digestive cancers. However, nitrofurantoin and tetracycline showed no association with digestive tumor incidence (Figure 3, Table 2). We also calculated the RRs (95\% CIs) to evaluate relationships between each anti-bacterial drug and the risk of cancer by organ site. Hepatobiliary, pancreatic, and anorectocolonic cancers were more closely related to antibacterial drug use, most notably with use of nitroimidazoles, sulphonamides, and quinolones (Table 2). The short-term use of anti-bacterial drugs (follow-up period $<5.98$ years) showed 
TABLE 1 | Summary of included study characteristics.

\begin{tabular}{|c|c|c|c|c|c|c|c|c|}
\hline References & Country & Design & $\begin{array}{l}\text { Follow-up } \\
\text { (years) }\end{array}$ & $\begin{array}{l}\text { Total cancer } \\
\text { cases }(n)\end{array}$ & $\begin{array}{l}\text { Cohort } \\
\text { (n) }\end{array}$ & $\begin{array}{l}\text { Data } \\
\text { format }\end{array}$ & $\begin{array}{l}\text { Anti-bacterial drugs } \\
\text { classification }^{c}\end{array}$ & $\begin{array}{l}\text { Tumor } \\
\text { Sites }\end{array}$ \\
\hline Fall et al. (24) & Sweden & Cohort & 11.8 & 645 & 501,757 & $\mathrm{SIR}$ & All anti-bacterial drug & Gastric \\
\hline $\begin{array}{l}\text { Kilkkinen } \\
\text { et al. (25) }\end{array}$ & Finland & Cohort & 7 & 26,373 & $3,112,624$ & $\mathrm{RR}$ & All anti-bacterial drug & $\begin{array}{l}\text { Esophagus, gastric, } \\
\text { duodenum, colon, } \\
\text { rectum, liver, gall } \\
\text { bladder, pancreas }\end{array}$ \\
\hline $\begin{array}{l}\text { Take et al. } \\
\text { (29) }\end{array}$ & Japan & Cohort & 3.9 & 13 & 1,342 & $\begin{array}{l}\text { Events } \\
\text { number }\end{array}$ & $\begin{array}{l}\text { Hp eradication in } \\
\text { patients with peptic } \\
\text { ulcer disease }\end{array}$ & Gastric \\
\hline Lee et al. (30) & China & Cohort & 8 & 31 & 4,121 & $\begin{array}{l}\text { Events } \\
\text { number }\end{array}$ & Hp eradication & Gastric \\
\hline Wu et al. (31) & China & Cohort & $5.92-7.22^{\mathrm{a}}$ & 249 & 80,255 & SIR & $\begin{array}{l}\text { Hp eradication in } \\
\text { patients with peptic } \\
\text { ulcer disease }\end{array}$ & Gastric \\
\hline $\begin{array}{l}\text { Didham et al. } \\
\text { (9) }\end{array}$ & New Zealand & $\begin{array}{l}\text { Nested } \\
\text { case-control }\end{array}$ & $4.5^{\mathrm{b}}$ & 1,189 & 6,500 & OR & $\begin{array}{l}\text { Penicillins, macrolides, } \\
\text { cephalosporins, } \\
\text { sulphonamides, } \\
\text { tetracycline, } \\
\text { nitrofurantoin }\end{array}$ & $\begin{array}{l}\text { Esophagus, stomach } \\
\text { and small intestine, } \\
\text { colorectal, liver, } \\
\text { pancreas and other } \\
\text { digestive }\end{array}$ \\
\hline $\begin{array}{l}\text { Friedman } \\
\text { et al. (6) }\end{array}$ & USA & $\begin{array}{l}\text { Nested } \\
\text { case-control }\end{array}$ & 12.5 & 79 & $6,608,681$ & $\mathrm{RR}$ & $\begin{array}{l}\text { Azithromycin, } \\
\text { ciprofloxacin, } \\
\text { clarithromycin, } \\
\text { sulfamethoxazole }\end{array}$ & $\begin{array}{l}\text { Anus, anal canal, } \\
\text { anorectum }\end{array}$ \\
\hline $\begin{array}{l}\text { Friedman } \\
\text { et al. (26) }\end{array}$ & USA & $\begin{array}{l}\text { Nested } \\
\text { case-control }\end{array}$ & 12 & 149 & $6,500,000$ & $\mathrm{RR}$ & Metronidazole & $\begin{array}{l}\text { Liver, intrahepatic bile } \\
\text { ducts, colon, anus, } \\
\text { anacanal, anorectum }\end{array}$ \\
\hline $\begin{array}{l}\text { Wang et al. } \\
(28)\end{array}$ & China & $\begin{array}{l}\text { Nested } \\
\text { case-control }\end{array}$ & 7.4 & 5,572 & 640,173 & $\begin{array}{l}\text { Events } \\
\text { number }\end{array}$ & $\begin{array}{l}\text { Anti-aerobic and } \\
\text { anti-anaerobic agents }\end{array}$ & Colon, rectal \\
\hline $\begin{array}{l}\text { Boursi et al. } \\
(10)\end{array}$ & UK & $\begin{array}{l}\text { Nested } \\
\text { case-control }\end{array}$ & $6-7$ & 16,654 & 615,951 & $\begin{array}{l}\text { Events } \\
\text { number }\end{array}$ & $\begin{array}{l}\text { Penicillins, macrolides, } \\
\text { cephalosporins, } \\
\text { sulfacetamides, } \\
\text { tetracyclines, } \\
\text { quinolones, } \\
\text { nitroimidazoles }\end{array}$ & $\begin{array}{l}\text { Esophagus, gastric, } \\
\text { hepatocellular, biliary, } \\
\text { gallbladder, pancreas }\end{array}$ \\
\hline $\begin{array}{l}\text { Boursi et al. } \\
(27)\end{array}$ & UK & $\begin{array}{l}\text { Nested } \\
\text { case-control }\end{array}$ & 6.5 & 20,990 & 103,044 & $\begin{array}{l}\text { Events } \\
\text { number }\end{array}$ & $\begin{array}{l}\text { Penicillins, macrolides, } \\
\text { cephalosporins, } \\
\text { sulfacetamides, } \\
\text { tetracyclines, } \\
\text { quinolones, } \\
\text { nitroimidazoles }\end{array}$ & Colorectal \\
\hline Dik et al. (23) & Netherlands & $\begin{array}{l}\text { Nested } \\
\text { case-control }\end{array}$ & 5 & 4,029 & 20,017 & $\begin{array}{l}\text { Events } \\
\text { number }\end{array}$ & $\begin{array}{l}\text { Penicillin, tetracyclines, } \\
\text { sulphonamides, } \\
\text { macrolides, quinolones, } \\
\text { nitrofurans }\end{array}$ & Colorectal \\
\hline $\begin{array}{l}\text { Yang et al. } \\
\text { (11) }\end{array}$ & UK & $\begin{array}{l}\text { Nested } \\
\text { case-control }\end{array}$ & 11 & 1,195 & 5,835 & $\begin{array}{l}\text { Events } \\
\text { number }\end{array}$ & All anti-bacterial drugs & Primary liver cancer \\
\hline $\begin{array}{l}\text { Correa et al. } \\
(32)\end{array}$ & Colombia & $\mathrm{RCT}$ & 6 & 5 & 1,219 & $\begin{array}{l}\text { Events } \\
\text { number }\end{array}$ & Hp eradication & Gastric \\
\hline $\begin{array}{l}\text { Wong et al. } \\
\text { (34) }\end{array}$ & China & $\mathrm{RCT}$ & 8 & 18 & 988 & $\begin{array}{l}\text { Events } \\
\text { number }\end{array}$ & Hp eradication & Gastric \\
\hline Li et al. (33) & China & $\mathrm{RCT}$ & 15 & 84 & 2,258 & $\begin{array}{l}\text { Events } \\
\text { number }\end{array}$ & Hp eradication & Gastric \\
\hline $\begin{array}{l}\text { Zhou et al. } \\
\text { (35) }\end{array}$ & China & $\mathrm{RCT}$ & 10 & 9 & 1,006 & $\begin{array}{l}\text { Events } \\
\text { number }\end{array}$ & Hp eradication & Gastric \\
\hline
\end{tabular}

$O R$, odds ratio; RR, risk ratio; $R C T$, randomized controlled trial; SIR: standardized incidence ratio; Hp, helicobacter pylori.

${ }^{a}$ Mean follow-up period for early Hp eradication population was 5.92 years, and the later eradication was 7.22 years.

${ }^{b}$ Follow-up period range from 2 to 7 years, we used the median 4.5 years.

c "Hp eradication" indicates anti-bacterial drugs classes used to treat Hp infection. 
Antibiotic exposure and digestive tumor incidence risk

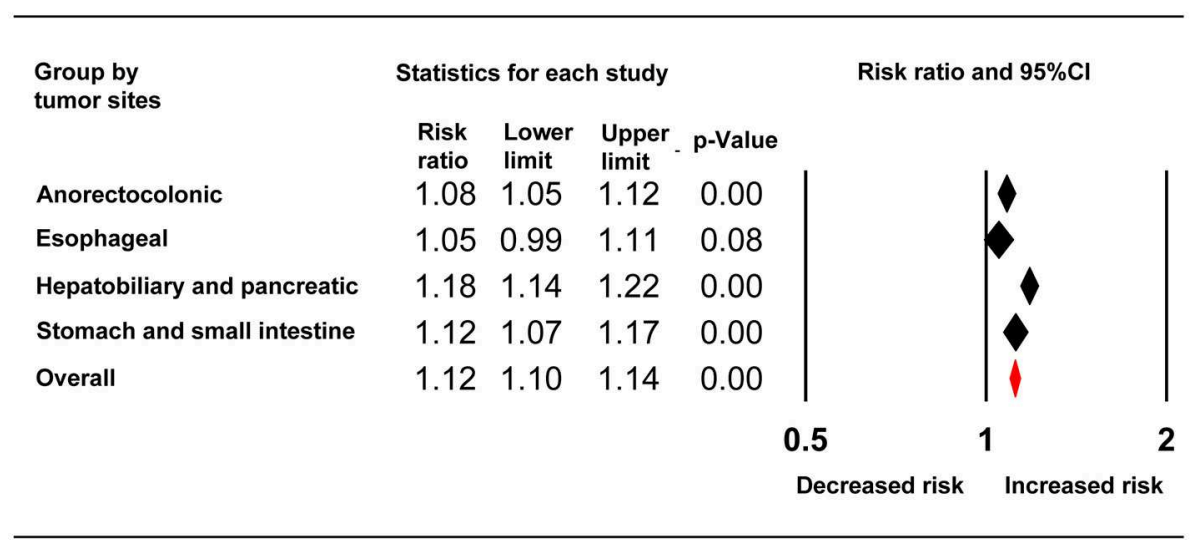

FIGURE 2 | Forest plot showing the relationship between whole anti-bacterial drug exposure and digestive system cancer risks grouped by tumor site.

TABLE 2 | Risk assessment of each anti-bacterial drug class and digestive cancer incidence.

\begin{tabular}{|c|c|c|c|c|c|}
\hline Anti-bacterial drugs & $\begin{array}{l}\text { Esophageal } \\
\text { cancer }\end{array}$ & $\begin{array}{l}\text { Stomach and small } \\
\text { intestine cancer }\end{array}$ & $\begin{array}{c}\text { Hepatobiliary } \\
\text { and pancreatic cancer }\end{array}$ & $\begin{array}{l}\text { Anorectocolonic } \\
\text { cancer }\end{array}$ & Overall \\
\hline Cephalosporins & $1.02(0.81-1.28)$ & $1.11(0.90-1.37)$ & $1.16(1.05-1.29)$ & 1.08 (0.98-1.19) & $1.12(1.05-1.18)$ \\
\hline Macrolides & $1.07(0.88-1.31)$ & $1.17(0.97-1.41)$ & $1.14(1.03-1.25)$ & $1.02(0.95-1.10)$ & $1.09(1.04-1.15)$ \\
\hline Nitrofurans & NA & $1.89(0.76-4.68)$ & $0.96(0.76-1.21)$ & $1.04(0.92-1.18)$ & $1.02(0.91-1.15)$ \\
\hline Nitroimidazoles & $1.08(0.83-1.40)$ & $1.11(0.86-1.43)$ & $1.22(1.07-1.39)$ & $1.21(1.09-1.34)$ & $1.17(1.09-1.26)$ \\
\hline Penicillins & $1.06(0.88-1.27)$ & 1.05 (0.89-1.24) & $1.11(1.02-1.21)$ & 1.07 (1.00-1.15) & $1.08(1.04-1.14)$ \\
\hline Quinolones & $1.13(0.88-1.45)$ & $1.13(0.89-1.43)$ & $1.26(1.12-1.41)$ & $1.16(1.06-1.27)$ & $1.18(1.11-1.26)$ \\
\hline Sulphonamides & $0.94(0.76-1.16)$ & $1.05(0.87-1.27)$ & $1.13(1.02-1.25)$ & $1.11(1.04-1.18)$ & $1.09(1.03-1.14)$ \\
\hline Tetracyclines & $1.02(0.82-1.24)$ & $1.05(0.87-1.26)$ & $1.09(0.98-1.21)$ & $0.98(0.91-1.05)$ & $1.03(0.97-1.09)$ \\
\hline Unknown & $1.00(0.81-1.24)$ & $1.16(1.06-1.27)$ & $1.37(1.27-1.48)$ & $1.14(1.07-1.21)$ & $1.20(1.16-.25)$ \\
\hline Overall & 1.05 (0.99-1.11) & $1.12(1.07-1.17)$ & $1.18(1.14-1.22)$ & 1.08 (1.05-1.12) & $1.12(1.10-1.14)$ \\
\hline
\end{tabular}

no statistically significant association with cancer incidence (RR, 1.03; 95\% CI, 0.99-1.07). Alternatively, the long-term use of anti-bacterial drugs slightly increased cancer risk, however, no obvious difference was seen between the $5.98-7.31$ years group (RR, $1.15 ; 95 \% \mathrm{CI}, 1.13-1.18)$ and the $>7.31$ years group (RR, 1.09; 95\% CI, 1.01-1.18, Supplementary Figure 4).

\section{Anti-bacterial Drug and Gastric Cancer}

Anti-bacterial drug exposure and gastric cancer event risk was evaluated in a combination of 11 studies, no obvious association was observed between gastric cancer and exposure to each individual anti-bacterial drug (Table 2). The RR (95\% CIs) for antibacterial agents used to eradicate $\mathrm{Hp}$ was $1.11(0.98-1.25)$, the risk was reduced to $0.69(0.50-0.97)$ after excluding 262 patients with peptic ulcer disease (Supplementary Figures 2, 3).

\section{Drug Dose Accumulation and Digestive System Cancer Risk}

Analysis of the subgroups of low, intermediate, and high antibacterial drug dose accumulation revealed that the digestive system cancer risks increased with the rise of medical prescriptions. The RRs (95\% CIs) for the low, intermediate, and high groups were: 1.08 (95\% CI, 1.05-1.11), 1.15 (95\% CI, 1.12-1.18), and 1.22 (95\% CI, 1.18-1.26), respectively. The dose accumulation effect on the risk of cancer was replicated in analyses among groups of cephalosporins, macrolides, penicillins, and quinolones (Figure 4).

\section{DISCUSSION}

We conducted the meta-analysis by combining 13 observational studies with four RCTs, a total of 77,284 digestive system cancer cases from a large population of $18,205,771$ individuals were included in our analyses. Statistically significant associations between anti-bacterial drug exposure and the risk of digestive cancers occurrence were observed, especially in the subgroups of anorectocolonic, hepatobiliary, and pancreatic cancers. Although only modest associations were observed, a significant connection between higher drug dose accumulation and higher cancer risk further substantiated the correlations.

In our study, populations with exposures to nitroimidazoles and quinolones had a higher cancer risk than any other 
Risk of different antibiotic use and digestive tumor incidence

\begin{tabular}{|c|c|c|c|c|c|c|}
\hline \multirow{2}{*}{$\begin{array}{l}\text { Group by } \\
\text { antibiotic }\end{array}$} & \multicolumn{4}{|c|}{ Statistics for each study } & \multirow{2}{*}{\multicolumn{2}{|c|}{ Risk ratio and $95 \% \mathrm{Cl}$}} \\
\hline & $\begin{array}{l}\text { Risk } \\
\text { ratio }\end{array}$ & $\begin{array}{l}\text { Lowe } \\
\text { limit }\end{array}$ & $\begin{array}{l}\text { r Upper } \\
\text { limit }\end{array}$ & $p$-Value & & \\
\hline Cephalosporins & 1.12 & 1.05 & 1.18 & 0.00 & & \\
\hline Macrolides & 1.09 & 1.04 & 1.15 & 0.00 & & \\
\hline Nitrofurans & 1.02 & 0.91 & 1.15 & 0.70 & & \\
\hline Nitroimidazoles & 1.17 & 1.09 & 1.26 & 0.00 & & \\
\hline Penicillins & 1.08 & 1.04 & 1.14 & 0.00 & & \\
\hline Quinolones & 1.18 & 1.11 & 1.26 & 0.00 & & \\
\hline Sulphonamides & 1.09 & 1.03 & 1.14 & 0.00 & & \\
\hline Tetracyclines & 1.03 & 0.97 & 1.09 & 0.31 & & \\
\hline Unknown & 1.20 & 1.16 & 1.25 & 0.00 & & \\
\hline \multirow[t]{3}{*}{ Overall } & 1.12 & 1.10 & 1.14 & 0.00 & & \\
\hline & & & & & 0.5 & $1 \quad 2$ \\
\hline & & & & & Decreased risk & Increased risk \\
\hline
\end{tabular}

FIGURE 3 | Forest plot of anti-bacterial drug use and risks of total digestive system cancers grouped by anti-bacterial drug class.

individual anti-bacterial drug class, these two anti-bacterial drug classes were commonly used to treat gastrointestinal infections or anaerobic bacterial infections $(36,37)$. Previous studies have suggested that recurrent infections and inflammatory diseases are related to higher cancer risks (38-40). Patients with weakened immune systems, such as smokers, diabetics, and those with cirrhosis, more frequently acquire infections requiring anti-bacterial drug treatment (41-44). Diabetes and cirrhosis were also identified as controlling factors that promote tumor development $(42,45)$. To our knowledge, three quarters of anti-bacterial drugs, such as cephalosporins, macrolides, sulphonamides, and penicillins, are used to treat respiratory tract infections (46). In the current study, there was no evidence to suggest a relationship between digestive system cancers and anti-bacterial drugs, however, slightly increased cancer risks were observed in our analysis. Thus, the correlation is unlikely to be induced completely by infection, and the anti-bacterial drugs are more likely used to treat infectious diseases related to digestive cancer, rather than a direct carcinogen.

A variety of studies support the theory that Helicobacter pylori (Hp) plays an important role in gastric cancer incidence and development $(47,48)$. Early $\mathrm{Hp}$ eradication is one important strategy in the prevention of gastric cancer (49). Anti-bacterial drugs used to treat $\mathrm{Hp}$ infections were correlated with a lower risk of gastric cancer in our analysis, and the risk was significantly reduced in patients without peptic ulcer diseases. Besides the effect of $\mathrm{Hp}$ eradication, there were two potential explanations for the decreased risks observed in our studies. First, the treatment course for $\mathrm{Hp}$ eradication is done over a short period of time (50), and increased cancer risk is generally observed in populations with long-term anti-bacterial drug exposure. Second, although $\mathrm{Hp}$ infection may be eradicated, irreversible initiation of tumorigenesis may exist in peptic ulcer patients.

There has been no evidence to suggest that anti-bacterial drugs have a direct carcinogenic effect on cancer development in previous investigations (51). We observed that high antibacterial drug dose accumulation and long-term anti-bacterial drug exposure significantly increased the risk of digestive cancer, which suggests that there is a relationship between anti-bacterial drug exposure and digestive system cancers. Our first hypothesis was that anti-bacterial drugs or their metabolites are carcinogens. Anti-bacterial drugs, including metronidazole and quinolones, have been proposed to have potential genotoxicity in previous studies $(52,53)$, and metronidazole has been shown to be metabolized to the carcinogen acetamide in the human body (54). Further, it has been suggested that anti-bacterial drugs are associated with colorectal cancer through increased the production of prostaglandins and up-regulation of cyclooxygenase-2, thus contributing to inflammation (55). Collectively, there is very limited evidence of a direct effect of anti-bacterial drugs on carcinogenesis.

Another possible explanation for the observed association is that anti-bacterial drug exposure induces changes in the composition of gut microbiota $(56,57)$. The important roles that vast microbial communities play in health and disease are being increasingly recognized. Disruption of the dynamic equilibrium disruption of the microbiota with the host can contribute to diseases, including malignancy (58). Previous studies have suggested that some microbes promote cancer development by regulating host cell signaling cascades or inducing histologic changes $(59,60)$. In addition, the 


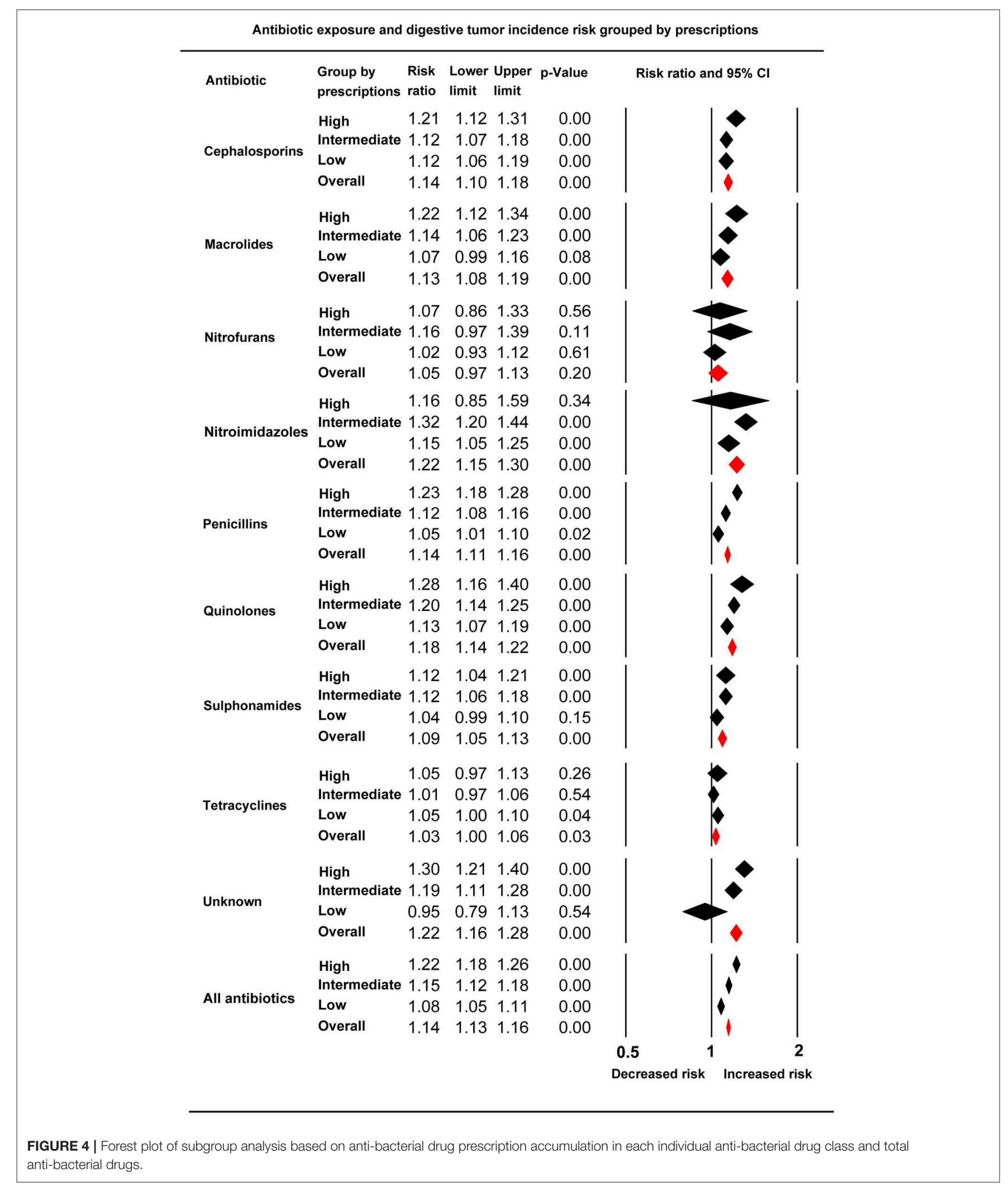

intestinal microbiota has been associated with the inhibition of carcinogenesis due the important role these microbiota play in the conversion of health-related compounds, such as phytochemicals, into bioactive compounds (51, 61). Anti-bacterial drug exposure reduces the composition and diversity of the intestinal microbiota, predominately composed 
of anaerobes, causing loss of beneficial bacteria and an increase in pathogenic microbes $(62,63)$. These changes may elevate the risk of hepatic tissue or intestinal mucosa exposure to toxic bacterial metabolites or products that may be carcinogenic $(57,60)$. Further, the intestinal microbiota plays an essential role in maintaining immune balance (64), and anti-bacterial drug exposure may disturb the microbiota and reduce the immune barrier function of the microbiota, which protects against tumor development. Other potential biological mechanisms or underlying concerns between anti-bacterial drugs use and cancers were not clarified. The above explanations are consistent with our results. Of the anti-bacterial drugs commonly used to treat gastrointestinal infections, quinolones and nitroimidazoles were significantly associated with an increased risk of cancer. However, the less used tetracyclines showed no relationship to cancer events. These results should be considered by clinicians when prescribing these anti-bacterial drugs.

\section{Strengths and Limitations}

To our knowledge, only one meta-analysis has evaluated the relationships between anti-bacterial drug exposure and cancer incidence risk. This study concluded that anti-bacterial drug ever-use is related to a slightly elevated breast cancer risk (65). A number of previous studies have investigated the uncertain association between anti-bacterial drugs and digestive system cancers. Our study was the first exhaustive metaanalysis conducted by combining these previous findings. We performed the analyses based on large study cohorts from multiple international population-based databases, including The Health Improvement Network database from the UK, the Population Register in Finland, the Swedish Inpatient Register, the Achmea Health Database in the Netherlands, and the Kaiser Permanente Medical Care Program in the USA. Each database provided comprehensive and representative data of medical diagnoses, demographics, and prescription pharmaceuticals prescribed for inpatients or outpatients. Finally, we conducted sub-analyses by drug dose accumulation and follow-up time, which further evaluated the association between anti-bacterial drugs and cancers.

Our study had several limitations. First, most of our included studies were observational, therefore, comprehensive information on residual confounding factors and the underlying diseases of patients was not available. If we ignore the dose accumulation response effect, the slightly increased risk of digestive cancer in our study may be partially explained by confounding factors and infections requiring anti-bacterial drug treatment. However, included studies were adjusted for some confounders such as sex, age, partial medical history including the use of acetylsalicylic acids, non-steroidal antiinflammatory drugs and acetylsalicylic acids. Second, although we conducted subgroup analyses based on follow-up period, the follow-up time duration did not reflect the actual exposure dose of anti-bacterial drugs. Third, most of included studies were retrospective, although we have try our best to contact authors via email. The dose of anti-bacterial drug use was not obtained. Fourth, the included patients may receive multiple antibiotics at the same time. All of the data was retrieved from patient demographics database. We can only conducted subgroups analysis in different antibacterial drugs. Finally, lack of information on anti-bacterial drug treatment indications or pathogens is another notable limitation. If we combine antibacterial drug exposure and infectious pathogens, additional values in evaluating the relationship between anti-bacterial drug exposure and digestive system cancer incidence may exist.

In conclusion, anti-bacterial drug exposure slightly increased the risk of total digestive system cancer development, and the risks were elevated with the rise of anti-bacterial drug dose accumulation. Nitroimidazoles (mainly metroimidazole) and quinolones showed a closer relationship to cancer, especially in anorectocolonic tumors and hepatobiliary and pancreatic malignancies. Anti-bacterial drug exposure may be a treatment indicator rather than a direct carcinogen. Changes in intestinal microbiota or immune defense deregulation induced by antibacterial drugs may be the indirect cause of increased cancer risks. More comprehensive information about treatment indications or underlying diseases would be valuable information to combine with our analyses.

\section{AUTHOR CONTRIBUTIONS}

CB: study concept and design, acquisition of data, analysis and interpretation of data, statistical analysis, drafting of the manuscript, critical revision of the manuscript, and approved final submission. KW: study concept and design, analysis and interpretation of data, drafting of the manuscript, critical revision of the manuscript, approved final submission, and study supervision. YD: acquisition of data, analysis and interpretation of data, statistical analysis, drafting of the manuscript, and technical or material support. JK: study concept and design, analysis and interpretation of data, drafting of the manuscript, critical revision of the manuscript, and approved final submission.

\section{FUNDING}

This work was supported by the National Natural Science Foundation of China (No. 81760743), the Guangxi Natural Science Foundation (No. 2016GXNSFAA380297), the Guangxi Zhuang Autonomous Region Health and Wellness Committee Science and Technology Project (No. S2019090), and the Basic Ability Improvement Project for Young and Middle-aged Teachers in Colleges of Guangxi (No. 2019KY0125).

\section{ACKNOWLEDGMENTS}

We thank LetPub (www.letpub.com) for its linguistic assistance during the preparation of this manuscript.

\section{SUPPLEMENTARY MATERIAL}

The Supplementary Material for this article can be found online at: https://www.frontiersin.org/articles/10.3389/fonc. 2019.01298/full\#supplementary-material 


\section{REFERENCES}

1. Bray F, Jemal A, Grey N, Ferlay J, Forman D. Global cancer transitions according to the Human Development Index (2008-2030): a populationbased study. Lancet Oncol. (2012) 13:790-801. doi: 10.1016/S1470-2045(12) 70211-5

2. Siegel R, Ma J, Zou Z, Jemal A. Cancer statistics, 2014. Cancer J Clin. (2014) 64:9-29. doi: $10.3322 /$ caac. 21208

3. Siegel R, Desantis C, Jemal A. Colorectal cancer statistics, 2014. Cancer J Clin. (2014) 64:104-17. doi: 10.3322/caac.21220

4. Anthony HM, Kenny TE, MacKinnon AU. Drugs in the aetiology of cancer: a retrospective study. Int J Epidemiol. (1982) 11:336-44. doi: 10.1093/ije/11.4.336

5. Hoover R, Fraumeni JF Jr. Drug-induced cancer. Cancer. (1981) 47(5 Suppl):1071-80. doi: 10.1002/1097-0142(19810301)47:5+<1071::AIDCNCR2820471304>3.0.CO;2-7

6. Friedman GD, Udaltsova N, Chan J, Quesenberry CP Jr, Habel LA. Screening pharmaceuticals for possible carcinogenic effects: initial positive results for drugs not previously screened. Cancer Causes Control. (2009) 20:182135. doi: 10.1007/s10552-009-9375-2

7. Zhang H, Garcia Rodriguez LA, Hernandez-Diaz S. Antibiotic use and the risk of lung cancer. Cancer Epidemiol Biomarkers Prev. (2008) 17:130815. doi: 10.1158/1055-9965.EPI-07-2817

8. Rasmussen ML, Hjalgrim H, Molgaard-Nielsen D, Wohlfahrt J, Melbye M. Antibiotic use and risk of non-Hodgkin lymphomas. Int J Cancer. (2012) 131:E1158-65. doi: 10.1002/ijc.27626

9. Didham RC, Reith DM, McConnell DW, Harrison KS. Antibiotic exposure and breast cancer in New Zealand. Breast Cancer Res Treat. (2005) 92:1637. doi: $10.1007 / \mathrm{s} 10549-005-2115-8$

10. Boursi B, Mamtani R, Haynes K, Yang YX. Recurrent antibiotic exposure may promote cancer formation-another step in understanding the role of the human microbiota? Eur J Cancer. (2015) 51:2655-64. doi: 10.1016/j.ejca.2015.08.015

11. Yang B, Hagberg KW, Chen J, Sahasrabuddhe VV, Graubard BI, Jick S, et al. Associations of antibiotic use with risk of primary liver cancer in the clinical practice research datalink. Br J Cancer. (2016) 115:859. doi: $10.1038 /$ bjc. 2016.148

12. Liberati A, Altman DG, Tetzlaff J, Mulrow C, Gotzsche PC, Ioannidis JP, et al. The PRISMA statement for reporting systematic reviews and meta-analyses of studies that evaluate health care interventions: explanation and elaboration. Ann Intern Med. (2009) 151:W65-94. doi: 10.7326/0003-4819-151-4-200908180-00136

13. Wells G, Shea BJ, O'Connell J. The Newcastle-Ottawa Scale (NOS) for Assessing the Quality of Nonrandomised Studies in Meta-analyses. Ottawa: Ottawa Hospital Research Institute Web site, (2014).

14. Zhao Z, Yin Z, Pu Z, Zhao Q. Association between consumption of red and processed meat and pancreatic cancer risk: a systematic review and meta-analysis. Clin Gastroenterol Hepatol. (2017) 15:48693.e10. doi: 10.1016/j.cgh.2016.09.143

15. DerSimonian R, Laird N. Meta-analysis in clinical trials. Control Clin Trials. (1986) 7:177-88. doi: 10.1016/0197-2456(86)90046-2

16. Laird NM, Mosteller F. Some statistical methods for combining experimental results. Int $J$ Technol Assess Health Care. (1990) 6:5-30. doi: 10.1017/S0266462300008916

17. Berkey CS, Hoaglin DC, Mosteller F, Colditz GA. A randomeffects regression model for meta-analysis. Stat Med. (1995) 14:395-411. doi: 10.1002/sim.4780140406

18. Begg CB, Mazumdar M. Operating characteristics of a rank correlation test for publication bias. Biometrics. (1994) 50:1088-101. doi: 10.2307/2533446

19. Egger M, Davey Smith G, Schneider M, Minder C. Bias in metaanalysis detected by a simple, graphical test. BMJ. (1997) 315:62934. doi: 10.1136/bmj.315.7109.629

20. Global Burden of Disease Cancer C, Fitzmaurice C, Dicker D, Pain A, Hamavid H, Moradi-Lakeh M, et al. The global burden of cancer 2013. JAMA Oncol. (2015) 1:505-27. doi: 10.1001/jamaoncol.2015.0735

21. Greenland S. Quantitative methods in the review of epidemiologic literature. Epidemiol Rev. (1987) 9:1-30. doi: 10.1093/oxfordjournals.epirev. a036298
22. Smith SJ, Caudill SP, Steinberg KK, Thacker SB. On combining dose-response data from epidemiological studies by meta-analysis. Stat Med. (1995) 14:53144. doi: $10.1002 / \operatorname{sim} .4780140513$

23. Dik VK, van Oijen MG, Smeets HM, Siersema PD. Frequent use of antibiotics is associated with colorectal cancer risk: results of a nested case-control study. Dig Dis Sci. (2016) 61:255-64. doi: 10.1007/s10620-015-3828-0

24. Fall K, Ye W, Nyren O. Antibiotic treatment and risk of gastric cancer. Gut. (2006) 55:793-6. doi: 10.1136/gut.2006.091850

25. Kilkkinen A, Rissanen H, Klaukka T, Pukkala E, Heliovaara M, Huovinen P, et al. Antibiotic use predicts an increased risk of cancer. Int J Cancer. (2008) 123:2152-5. doi: 10.1002/ijc.23622

26. Friedman GD, Jiang SF, Udaltsova N, Quesenberry CP Jr, Chan J, Habel LA. Epidemiologic evaluation of pharmaceuticals with limited evidence of carcinogenicity. Int J Cancer. (2009) 125:2173-8. doi: 10.1002/ijc.24545

27. Boursi B, Haynes K, Mamtani R, Yang YX. Impact of antibiotic exposure on the risk of colorectal cancer. Pharmacoepidemiol Drug Safety. (2015) 24:534-42. doi: 10.1002/pds.3765

28. Wang JL, Chang $\mathrm{CH}$, Lin JW, Wu LC, Chuang LM, Lai MS. Infection, antibiotic therapy and risk of colorectal cancer: a nationwide nested casecontrol study in patients with Type 2 diabetes mellitus. Int J Cancer. (2014) 135:956-67. doi: 10.1002/ijc.28738

29. Take S, Mizuno M, Ishiki K, Nagahara Y, Yoshida T, Yokota K, et al. Baseline gastric mucosal atrophy is a risk factor associated with the development of gastric cancer after Helicobacter pylori eradication therapy in patients with peptic ulcer diseases. J Gastroenterol. (2007) 42(Suppl 17):217. doi: 10.1007/s00535-006-1924-9

30. Lee YC, Chen TH, Chiu HM, Shun CT, Chiang H, Liu TY, et al. The benefit of mass eradication of Helicobacter pylori infection: a community-based study of gastric cancer prevention. Gut. (2013) 62:67682. doi: 10.1136/gutjnl-2012-302240

31. Wu CY, Kuo KN, Wu MS, Chen YJ, Wang CB, Lin JT. Early Helicobacter pylori eradication decreases risk of gastric cancer in patients with peptic ulcer disease. Gastroenterology. (2009) 137:1641-8.e1-2. doi: 10.1053/j.gastro.2009.07.060

32. Correa P, Fontham ET, Bravo JC, Bravo LE, Ruiz B, Zarama G, et al. Chemoprevention of gastric dysplasia: randomized trial of antioxidant supplements and anti-helicobacter pylori therapy. J Natl Cancer Instit. (2000) 92:1881-8. doi: 10.1093/jnci/92.23.1881

33. Li WQ, Ma JL, Zhang L, Brown LM, Li JY, Shen L, et al. Effects of Helicobacter pylori treatment on gastric cancer incidence and mortality in subgroups. J Natl Cancer Instit. (2014) 106:dju116. doi: 10.1093/jnci/dju116

34. Wong B, Lam S, Wong W, Chen J, Zheng T, Feng R, et al. Helicobacter pylori eradication to prevent gastric cancer in a highrisk region of China: a randomized controlled trial. JAMA. (2004) 291:187-94. doi: 10.1001/jama.291.2.187

35. Zhou L, Lin S, Ding S, Huang X, Jin Z, Cui R, et al. Relationship of Helicobacter pylori eradication with gastric cancer and gastric mucosal histological changes: a 10-year follow-up study. Chin Med J. (2014) 127:14548. doi: 10.3760/cma.j.issn.0366-6999.20132494

36. Naeem A, Badshah SL, Muska M, Ahmad N, Khan K. The current case of quinolones: synthetic approaches and antibacterial activity. Molecules. (2016) 21:268. doi: $10.3390 /$ molecules 21040268

37. Leitsch D. A review on metronidazole: an old warhorse in antimicrobial chemotherapy. Parasitology. (2019) 146:11671178. doi: 10.1017/S0031182017002025

38. Herrera LA, Benitez-Bribiesca L, Mohar A, Ostrosky-Wegman P. Role of infectious diseases in human carcinogenesis. Environ Mol Mutag. (2005) 45:284-303. doi: 10.1002/em.20122

39. Oliveira MJ, Velho S. The association between inflammation and colorectal cancer. Mol Pathog Colorectal Cancer. (2013) 67-105. doi: 10.1007/978-1-4614-8412-7_3

40. Karin M, Lawrence T, Nizet V. Innate immunity gone awry: linking microbial infections to chronic inflammation and cancer. Cell. (2006) 124:82335. doi: 10.1016/j.cell.2006.02.016

41. Wu HP, Chu CM, Lin CY, Yu CC, Hua CC, Yu TJ, et al. Liver cirrhosis and diabetes mellitus are risk factors for Staphylococcus aureus infection in patients with healthcare-associated or hospital-acquired pneumonia. Pulm Med. (2016) 2016:4706150. doi: 10.1155/2016/4706150 
42. Davila JA, Morgan RO, Shaib Y, McGlynn KA, El-Serag HB. Diabetes increases the risk of hepatocellular carcinoma in the United States: a population based case control study. Gut. (2005) 54:533-9. doi: 10.1136/gut.2004.052167

43. Steinberg MB, Akincigil A, Kim EJ, Shallis R, Delnevo CD. Tobacco smoking as a risk factor for increased antibiotic prescription. Am J Prev Med. (2016) 50:692-8. doi: 10.1016/j.amepre.2015. 11.009

44. Navasa M, Rimola A, Rodes J. Bacterial infections in liver disease. Semin Liver Dis. (1997) 17:323-33. doi: 10.1055/s-2007-1007209

45. Payet M. Cirhosis \& primary cancer of the liver. Rev Prat. (1958) 8:629-31.

46. Rautakorpi UM, Huikko S, Honkanen P, Klaukka T, Makela M, Palva E, et al. The Antimicrobial Treatment Strategies (MIKSTRA) program: a 5year follow-up of infection-specific antibiotic use in primary health care and the effect of implementation of treatment guidelines. Clin Infect Dis. (2006) 42:1221-30. doi: 10.1086/503036

47. Møller H, Heseltine E, Vainio H. Schistosomes, liver flukes and Helicobacter pylori. In: IARC Monographs on the Evaluation of Carcinogenic Risks to Humans. Vol. 61. Lyon: IARC Working Group on the Evaluation of Carcinogenic Risks to Humans (1994), p. 1-241.

48. Plummer M, de Martel C, Vignat J, Ferlay J, Bray F, Franceschi S. Global burden of cancers attributable to infections in 2012: a synthetic analysis. Lancet Glob Health. (2016) 4:e609-16. doi: 10.1016/S2214-109X(16)30143-7

49. Malfertheiner P, Megraud F, O'Morain CA, Atherton J, Axon AT, Bazzoli F, et al. Management of Helicobacter pylori infection-the Maastricht IV/Florence Consensus Report. Gut. (2012) 61:646-64. doi: 10.1136/gutjnl-2012302084

50. Louw JA, van Rensburg CJ, Hanslo D, Grundlings HD, Girdwood AH, Marks IN. Two-week course of pantoprazole combined with 1 week of amoxycillin and clarithromycin is effective in Helicobacter pylori eradication and duodenal ulcer healing. Aliment. Pharmacol Therap. (1998) 12:54550. doi: 10.1046/j.1365-2036.1998.00343.x

51. Snyder RD. An update on the genotoxicity and carcinogenicity of marketed pharmaceuticals with reference to in silico predictivity. Environ Mol Mutag. (2009) 50:435-50. doi: 10.1002/em.20485

52. Itoh $\mathrm{T}$, Mitsumori K, Kawaguchi S, Sasaki YF. Genotoxic potential of quinolone antimicrobials in the in vitro comet assay and micronucleus test. Mutat Res. (2006) 603:135-44. doi: 10.1016/j.mrgentox.2005. 11.003

53. Brambilla G, Mattioli F, Robbiano L, Martelli A. Studies on genotoxicity and carcinogenicity of antibacterial, antiviral, antimalarial and antifungal drugs. Mutagenesis. (2012) 27:387-413. doi: 10.1093/mutage/ger094

54. Goldman P. Metronidazole: proven benefits and potential risks. Johns Hopkins Med J. (1980) 147:1-9.
55. Dixon DA, Blanco FF, Bruno A, Patrignani P. Mechanistic aspects of COX-2 expression in colorectal neoplasia. Recent Results Cancer Res. (2013) 191:737. doi: 10.1007/978-3-642-30331-9_2

56. Ahn J, Sinha R, Pei Z, Dominianni C, Wu J, Shi J, et al. Human gut microbiome and risk for colorectal cancer. J Natl Cancer Instit. (2013) 105:1907-11. doi: 10.1093/jnci/djt300

57. Schwabe RF, Jobin C. The microbiome and cancer. Nat Rev Cancer. (2013) 13:800-12. doi: 10.1038/nrc3610

58. Kwa M, Plottel CS, Blaser MJ, Adams S. The intestinal microbiome and estrogen receptor-positive female breast cancer. J Natl Cancer Instit. (2016) 108. doi: 10.1093/jnci/djw029

59. Garrett WS. Cancer and the microbiota. Science. (2015) 348:806. doi: 10.1126/science.aaa4972

60. Gagnaire A, Nadel B, Raoult D, Neefjes J, Gorvel JP. Collateral damage: insights into bacterial mechanisms that predispose host cells to cancer. Nat Rev Microbiol. (2017) 15:109-28. doi: 10.1038/nrmicro.2016.171

61. Kilkkinen A, Pietinen P, Klaukka T, Virtamo J, Korhonen P, Adlercreutz H. Use of oral antimicrobials decreases serum enterolactone concentration. Am J Epidemiol. (2002) 155:472-7. doi: 10.1093/aje/155.5.472

62. Sullivan A, Edlund C, Nord CE. Effect of antimicrobial agents on the ecological balance of human microflora. Lancet Infect Dis. (2001) 1:10114. doi: 10.1016/S1473-3099(01)00066-4

63. Rashid MU, Weintraub A, Nord CE. Effect of new antimicrobial agents on the ecological balance of human microflora. Anaerobe. (2012) 18:24953. doi: 10.1016/j.anaerobe.2011.11.005

64. Kamada N, Nunez G. Regulation of the immune system by the resident intestinal bacteria. Gastroenterology. (2014) 146:147788. doi: 10.1053/j.gastro.2014.01.060

65. Sergentanis TN, Zagouri F, Zografos GC. Is antibiotic use a risk factor for breast cancer? A meta-analysis. Pharmacoepidemiol Drug Safety. (2010) 19:1101-7. doi: $10.1002 /$ pds. 1986

Conflict of Interest: The authors declare that the research was conducted in the absence of any commercial or financial relationships that could be construed as a potential conflict of interest.

Copyright (c) 2019 Bao, Wang, Ding and Kong. This is an open-access article distributed under the terms of the Creative Commons Attribution License (CC BY).

The use, distribution or reproduction in other forums is permitted, provided the original author(s) and the copyright owner(s) are credited and that the original publication in this journal is cited, in accordance with accepted academic practice. No use, distribution or reproduction is permitted which does not comply with these terms. 